\title{
Chemical weathering fluxes from Paramushir volcanic island (Kuril Island arc, Russia)
}

\author{
Elena Kalacheva ${ }^{1, *}$, Tatiana Kotenko ${ }^{1}$, and Ekaterina Voloshina $^{1}$ \\ ${ }^{1}$ Institute of Volcanology and Seismology, FEB RAS, Petropavlovsk-Kamchatsky 683006, Russia
}

\begin{abstract}
The rates of the chemical erosion for Paramushir Island, north Kuril Arc, were studied. The rates of the chemical erosion for Paramushir Island, north Kuril Arc, were studied. They were based on the results of the flow rate measurements and chemical analyses of 35 river's water, sampled in July 2017. The silicate weathering fluxes caused by the subsurface thermal and two different types of surface waters (acid $\mathrm{SO}_{4}$ and nearneutral $\left.\mathrm{Na}(\mathrm{Ca})-\mathrm{HCO}_{3}\right)$ of Paramushir have been estimated as $1095 \pm 200$, $203 \pm 100$ and $64 \pm 20 \mathrm{t} / \mathrm{km}^{2} /$ year, respectively. The total chemical weathering flux for Paramushir Island is estimated as $120 \pm 40 \mathrm{t} / \mathrm{km}^{2} /$ year.
\end{abstract}

\section{Introduction}

Water-rock interaction, including hydrolysis reactions cause rock destruction and removal of elements from the crystalline lattice of minerals. In the areas of recent and modern island-arc volcanism, chemical erosion of volcanic rocks represents one of the most intense type of silicate weathering. The hydrothermal activity associated with active volcanoes edifices produces extreme conditions in which intense water-rock interactions occur and may have a strong impact on the weathering budget. Removal of dissolved matter (cations $+\mathrm{SiO}_{2}$ ) (DCPS) by surface flows also affects the stability of volcanic edifices and the chemical composition of the surrounding seas and oceans. The chemical weathering rates from volcanic islands in tropical areas have been first estimated in [4] as 10-20 times more efficient than from other environments. For the first time the chemical erosion rate from a volcanic island at a latitude of $\sim 48.5^{\circ} \mathrm{N}$ (Shiashkotan Island, Kuril Island arc) has been estimated by Kalacheva et al. [2] as 2-5 times less efficient than that of tropical islands. Here we present the first details data of the surface and subsurface chemical fluxes by rivers of Paramushir, northern Kuril Islands.

\section{Geological and hydrological settings}

Paramushir Island (Fig. 1) whose area equal to $2042 \mathrm{~km}^{2}$ is one of the largest islands of the Kurils. It extends from the south-west to the north-east for more than $100 \mathrm{~km}$ with anaverage width of $20-25 \mathrm{~km}$. Chikurachki volcano summit is the highest point of the Island $(1816 \mathrm{~m})$. The Island hosts about ten Quaternary volcanoes, five of which are active

*Corresponding author: keg@kscnet.ru 
(Ebeko, Chikurachki, Tatarinov, Karpinsky, and Fuss Peak). Volcanic edifices merge at the basements forming the Vernadsky and Karpinsky ridges stretching along the island. All of the Quaternary massifs are composed of basalt to andesite rocks.

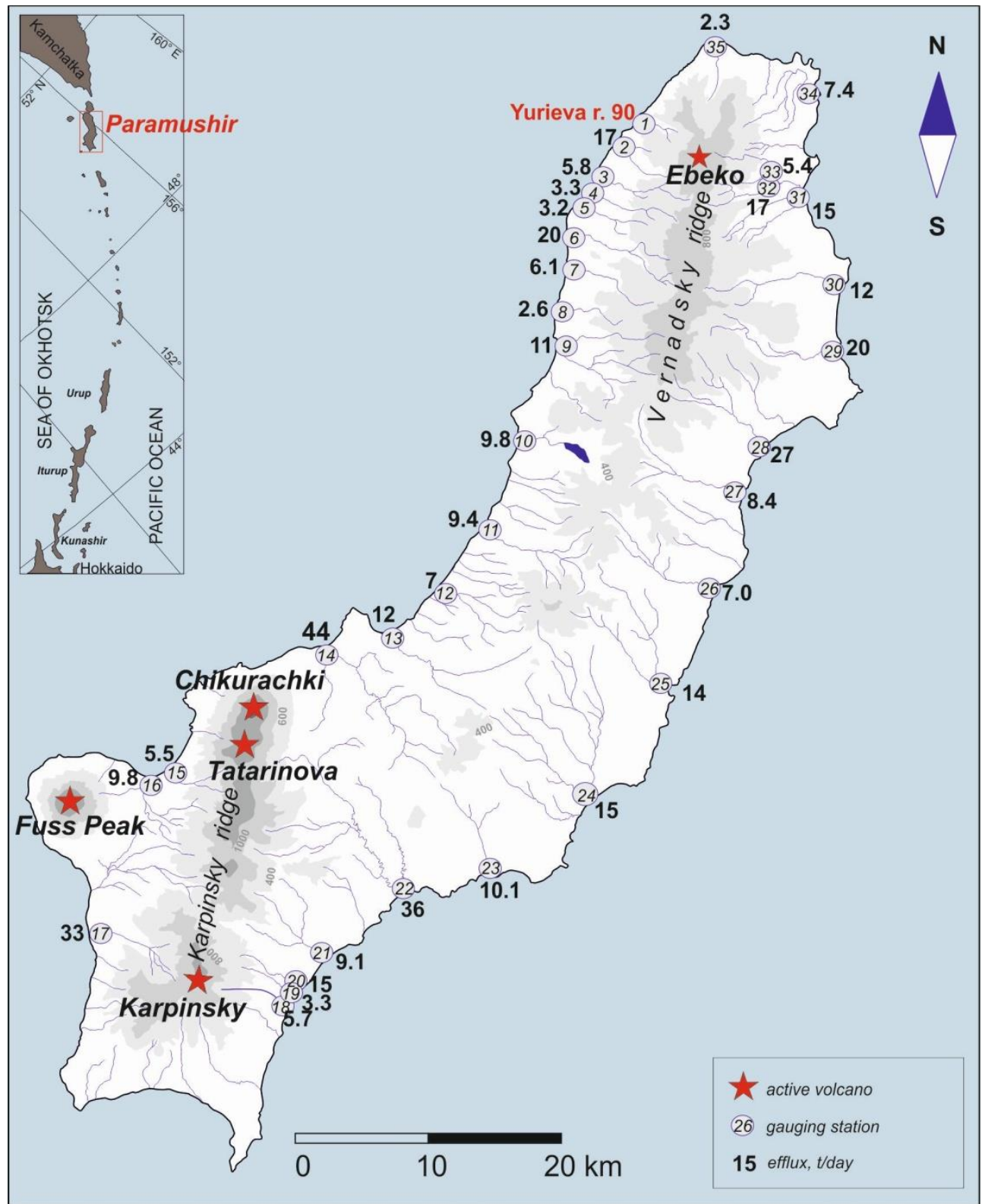

Fig. 1. Map of Paramushir Island with points of sampling and river's flux ( $t / d a y)$.

Rivers of Paramushir flow into the Sea of Okhotsk and the Pacific Ocean. Major watersheds are volcanic ridges controlling the latitudinal orientation of the river-valleys, the latter being generally canyon-shaped, with numerous rapids and waterfalls. Mouth areas host vast alluvial plains. Somewhat different are rivers of the central part of the island with gentle longitudinal profiles and relatively moderate flow-rates. The climate of the island is 
oceanic with the mean annual temperature of $\sim\left(3^{\circ} \mathrm{C}\right)$ being about $\left(+10^{\circ} \mathrm{C}\right)$ in August and $(-$ $5^{\circ} \mathrm{C}$ ) in January. The average annual rainfall is $\sim 1790 \mathrm{~mm} / \mathrm{yr}$.

\section{Methods}

In the course of the 2017 field works, 35 largest water-streams were sampled (fig 1). Water samples were filtered in situ through $0.45 \mu \mathrm{m}$ filters and collected in plastic bottles. Using orion multimeter were measured temperature $\left( \pm 0.1^{\circ} \mathrm{C}\right), \mathrm{pH}( \pm 0.05$ units) and conductivity $( \pm 2 \%)$ were measured on site by an Orion multimeter. Samples for major cations analyses were acidified with ultra-pure nitric acid. Concentrations of major aqueous species $(\mathrm{Na}, \mathrm{K}$, $\mathrm{Ca}, \mathrm{Mg}, \mathrm{Cl}, \mathrm{SO}_{4}$ ) were determined using ionic chromatography. Alkalinity as $\mathrm{HCO}_{3}{ }^{-}$was measured by titration using $0.1 \mathrm{M} \mathrm{HCl}$ solution. Total $\mathrm{SiO}_{2}$ were determined by the colorimetry.

We used a standard FP311 Global Water flow probe to measure the flow rate of streams. The total relative error of the measured flow rate does not exceed $10 \%$.

The catchment areas for rivers were calculated using Google Earth with the errors not less than $30 \%$

\section{Results and discussion}

The table shows field data for the rivers sampled in July 2017.

Table. Short characteristic major types river water and weathering.

\begin{tabular}{|c|c|c|c|c|c|c|c|c|}
\hline \multirow[b]{2}{*}{$\begin{array}{l}\text { Type of } \\
\text { water }\end{array}$} & \multirow[b]{2}{*}{ River } & \multirow[b]{2}{*}{$\mathrm{pH}_{\text {field }}$} & \multicolumn{2}{|c|}{ Average value } & \multirow[b]{2}{*}{$\begin{array}{l}\text { Flux } \\
\text { t/day }\end{array}$} & \multicolumn{2}{|c|}{ Total } & \multirow[b]{2}{*}{$\begin{array}{l}\text { Weathering } \\
\text { rate, } \\
\mathbf{t} / \mathbf{k m}^{2} / \mathbf{y r}\end{array}$} \\
\hline & & & $\begin{array}{l}\text { TDS, } \\
\text { mg/L }\end{array}$ & $\begin{array}{c}\text { TDS } \\
\left(\mathrm{cat}+\mathrm{SiO}_{2}\right), \\
\mathrm{mg} / \mathrm{L}\end{array}$ & & $\begin{array}{c}\mathbf{Q} \\
\mathbf{m}^{3} / \mathbf{s}\end{array}$ & $\begin{array}{c}\text { Square, } \\
\text { km }^{2}\end{array}$ & \\
\hline $\begin{array}{c}\text { Near neutral } \\
\mathrm{Na}(\mathrm{Ca})- \\
\mathrm{HCO}_{3}\end{array}$ & \begin{tabular}{|c} 
Number* 6- \\
$12,14-16$, \\
$21-25,27$, \\
28 \\
\end{tabular} & $6-7.5$ & 50 & 35 & 175 & $70 \pm 14$ & $\sim 1000$ & $64 \pm 20$ \\
\hline Acid $\mathrm{SO}_{4}$ & \begin{tabular}{|c|} 
Number 2 - \\
$5,13,17-20$, \\
$26,29,30$ - \\
35
\end{tabular} & $3-6$ & 140 & 75 & 236 & $50 \pm 10$ & $\sim 430$ & $203 \pm 80$ \\
\hline $\begin{array}{c}\text { Ultra-acid } \\
\mathrm{SO}_{4}-\mathrm{Cl}\end{array}$ & 1 - Yurieva & 1.9 & 2400 & 500 & 90 & 2 & $\sim 30$ & $1095 \pm 200$ \\
\hline - number $\mathrm{c}$ & fig. 1 . & ed a & $e$ & $\pm 40 \mathbf{t} / \mathbf{k r}$ & & & & \\
\hline
\end{tabular}

The chemical composition of the Paramushir rivers is controlled by 3 main factors: atmospheric input, surface low-temperature weathering of fresh and altered rocks and the mixing with thermal waters unloading in river valleys. Being based on physical and chemical parameters stream waters can be divided into three groups (fig. 2):

1) Fresh waters with $\mathrm{TDS}<50 \mathrm{mg} / \mathrm{L}, \mathrm{pH}$ from 6.5 to 7.5 , and $\mathrm{Na}(\mathrm{Ca})-\mathrm{HCO}_{3}$ composition. This group includes the rivers draining the central (non-volcanic) areas of the island and rocks composing the flanks of volcanic ridges.

2) Acid $\mathrm{SO}_{4}$ water have TDS up to $300 \mathrm{mg} / \mathrm{L}$. This group includes the rivers draining the hydrothermally altered slopes of volcanic edifices or modern fumarolic fields. In the heads of these rivers there are hot vents discharging thermal or cold acid saline waters.

3) Ultra-acid $\mathrm{Cl}-\mathrm{SO}_{4}$ waters enriched in cations including $\mathrm{Fe}$ and $\mathrm{Al}$. A characteristic example is the most well-studied river of the island - the Yurieva River that drains the 
ultra-acid Yurievskie hot springs. The springs themselves discharge high-TDS thermal waters formed due to absorption of volcanic gasses within the constrained groundwater aquifer [3]. The Yurieva River water shows Fe and Al concentrations of 43 and $105 \mathrm{mg} / \mathrm{L}$, respectively.
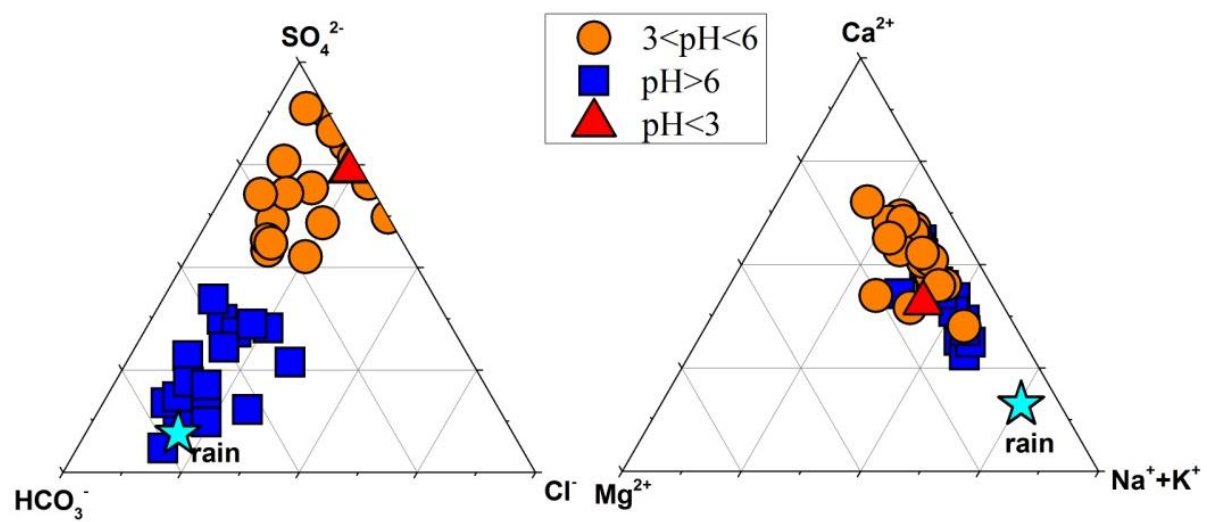

Fig. 2. Chemical composition of river water of Paramushir Island (mg/L).

For our calculations we used the data on cations $(\mathrm{Na}, \mathrm{K}, \mathrm{Ca}, \mathrm{Mg})$ and $\mathrm{SiO}_{2}$ corrected by the concentrations of these elements in rainfall waters. According to $2017 \mathrm{yr}$ data, the total dissolved cations together with $\mathrm{SiO}_{2}$ in river waters of Paramishir Island is about $500 \mathrm{t} /$ day (fig. 1).

Concentrations of DCPS in river waters of the first type (surface flux) range from 25 to $45 \mathrm{mg} / \mathrm{L}$. The average concentration is $35 \mathrm{mg} / \mathrm{L}$ (Table). The total discharge of this river's type is $70 \pm 10 \mathrm{~m}^{3} / \mathrm{s}$. The total rock-forming component efflux produced by the streams is about $175 \mathrm{t} /$ day. Taking into account the area of the island where the rivers of this type are located $\left(\sim 1000 \mathrm{~km}^{2}\right)$, the surface of chemical weathering can be estimated as $64 \pm 20$ $\mathrm{t} / \mathrm{km}^{2} /$ year (Table). It almost two times exceeds the values previously reported for Shiashkotan Island for the same type of waters [2].

Average concentration of DCPS in acid sulfate rivers draining old geothermal fields makes $75 \mathrm{mg} / \mathrm{L}$ with the total discharge of $50 \pm 10 \mathrm{~m}^{3} / \mathrm{s}$. This causes a mixed-type erosion of $230 \pm 40 \mathrm{t} / \mathrm{km}^{2} /$ year in areas that had undergone the hydrothermal alteration.

Ultra-acid chloride-sulfate the Yurieva River daily discharges about 90 ton of the dissolved solids ( $\mathrm{SiO}_{2}, \mathrm{Na}, \mathrm{K}, \mathrm{Ca}, \mathrm{Mg}, \mathrm{Fe}$ and $\mathrm{Al}$ ). This makes about $20 \%$ of the total rockforming component efflux produced by the streams of Paramushir Island (about 500 t/day). Area of the ultra-acid thermal waters is constrained by the complex edifice of Ebeko volcano (about $2 \%$ of the total area of the island). Chemical erosion induced by these waters is therefore 10 times more intense than the average over this island and makes about $1095 \pm 200 \mathrm{t} / \mathrm{km}^{2} /$ year.

\section{Concluding remarks}

Based upon the results of hydrochemical sampling and hydrological measurements conducted in July 2017, the silicate weathering fluxes caused by the subsurface thermal and two different types of surface waters (acid $\mathrm{SO}_{4}$ and near-neutral $\mathrm{Na}(\mathrm{Ca})-\mathrm{HCO}_{3}$ ) of Paramushir have been estimated as 1095 $\pm 200,203 \pm 100$ and $64 \pm 20 \mathrm{t} / \mathrm{km}^{2} /$ year, respectively. The total chemical weathering flux for Paramushir Island estimated as $120 \pm 40$ $\mathrm{t} / \mathrm{km}^{2} /$ year. The results are however considered preliminary. In the calculations were 
involved only apart $(75 \%)$ of the surface drainage. At the same time, estimates of the surface chemical erosion at Paramushir show values 10-15 times exceeding the average rate of the global silicate weathering $\left(7 \mathrm{t} / \mathrm{km}^{2} /\right.$ year [1]), Similar measurements were carried out for tropical islands of Guadeloupe (Lesser Antilles) and Reunion yielded values of 290 and $270 \mathrm{t} / \mathrm{km}^{2} /$ year [4], while those we earlier estimated for Shiashkotan (Kuril Islands) had shown $\sim 140 \mathrm{t} / \mathrm{km}^{2} /$ year [2]. More study is needed to make precise estimation of the weathering fluxes at the Kuril Islands because there are strong seasonal variations in the flow rates of the rivers and very complicated climatic conditions (about 7 months of the snow cover).

The authors thank to Dmitry Kuzmin and the crew of the Ashura boat for their assistance during the field works.

This study was supported by grant \# 15-17-20011 of the Russian Science Foundation.

\section{References}

1. J. Gaillardet, B. Dupre, P. Louvat, C.J. Allegre, Chem. Geol., 159, 3 (1999)

2. E. Kalacheva, Y. Taran, T.Kotenko, JVGR, 296, 40 (2015)

3. E. Kalacheva, Y. Taran, T. Kotenko et al.,JVGR, 310, 118 (2016)

4. S.D. Rad, C.J. Allègre, P. Louvat, Earth Planet. Sci. Lett., 262, 109 (2007) 